\title{
Reflections on Teaching Role Transformation of University Teachers in the New Period
}

\author{
Huihua Liu \\ Linyi University Feixian Campus \\ Linyi, China 273400
}

\begin{abstract}
With the rapid development of educational information technology in the new era, traditional teaching environment has undergone tremendous changes, and teachers' roles transformation has become an inevitable trend. Based on the new characteristics of higher education in the information era, this paper expounds the transformation of teachers' role from traditional authority to learners, developers, cooperators, guides and researchers in the information age. New equal, democratic and cooperative relationships of mutual respect, mutual trust, and mutual understanding between teachers and students are constructed.
\end{abstract}

Keywords—college; information technology; teachers' roles

\section{INTRODUCTION}

Han Yu once said: "teaching students the truth of doing things and to take the initiative to learn valuable qualities"; this is where the teacher's job lies. In the 21st century, mankind enters the era of knowledge economy, and information technologies change with each passing day. Multi-media technologies, communication technologies and network technologies have penetrated into all aspects of higher education. Therefore, with the background of China actively promoting education informatization and modernization, university teachers, working to infuse life blood into education, have no excuse for avoiding their duties to advocate and explore the teaching reform of information technology and curriculum integration in the innovation, and fully recognize the necessity of teachers' roles conversion and change roles accurately so as to improve themselves continuously and become qualified main drivers of changes.

\section{ROLE TRANSFORMATION OF UNIVERSITY TEACHERS IS INEVITABLE IN THE DEVELOPMENT OF TIMES}

When modern educational technology, especially computer technology, is applied to education and teaching, the traditional relationship between teachers and students has undergone great changes, and teachers will no longer function as the main communicators of knowledge and messenger. Because teachers' authority is challenged, role transformation has become an inevitable choice. With the continuous development of technology, educational technology, as an aid to teaching, is going through enormous changes both in materialized and conceptual form. Inevitably, it has a tremendous impact on the social status of education, the mode of knowledge transmission, educational goals, curriculum, undergraduates and teachers and so on, and these changes will change people's understanding of teachers' roles, and mean that the role transformation of teachers in modern educational technology is inevitable.

The application of information education technology poses challenges to teachers in the traditional sense: a series of teaching activities such as traditional classrooms, platforms, blackboards, desks, and board writing, demonstrations, and homework correcting are all very familiar to teachers. Moreover, a fairly large number of teachers have accumulated rich teaching experience in this environment. However, when all of these are replaced by the products supported by technology such as network, screen, informatization, and unified printed words, the frustration of teachers can be imagined, and what's more importantly, the position of absolute control has no longer existed. Under the condition of modern educational technology, the interaction between college teachers and undergraduates no longer mainly uses language as the only means of communication, but shows a tendency of diversification. Diversified means of communication makes teaching be carried out in wider scale, can mobilize more enthusiasm of undergraduates, and achieve the optimum target of teaching. Under the condition of modern educational technology, the gradual change of educational goals, concepts, curricula and the relationship between teachers and students forces teachers to reexamine their own roles, and require them to get rid of traditional roles and then play new roles, so that the conversion of teachers' roles has become the inevitable development of times. Therefore, it can be concluded that the challenge of information education technology on teachers is not the disappearance of teacher profession, but re-examination and reorientation of teachers on their own professions.

In the long run of national development, the development of information education technology profoundly affects the process of education informatization and the concrete implementation of the strategy of "rejuvenating the country through science and education", as well as China's position in talent competition in international competition in the $21 \mathrm{st}$ century. The use of information education technology has changed education from traditional closed information to open information system, expanding education scale, improving education quality, lowering education cost and increasing the profits of teaching. Because of the information education technology transforms traditional education 
system of people and people composed of university teachers and undergraduates into a new system of people, machines and people formed by teachers, teaching machines and undergraduates. Teachers are pushed from the front to the back of the stage. In spite of this, the application of information education technology must mobilize and rely on teachers. Therefore, as far as teachers are concerned, they need to know the impact of the transformation of information education technology on education informatization, and should re-position their own roles in the new education system of "people and machines and people". Only in this way can teachers conscientiously occupy the "commanding heights" of education and undertake the historical mission endowed by information education.

\section{THE TRANSFORMATION STRATEGY OF UNIVERSITY TEACHERS' ROLES UNDER THE NEW SITUATION}

\section{A. Innovating Boldly and Changing the Teaching Concepts of University Teachers}

The development of science and technology brings us new educational technologies. They are the keys how college teachers adapt to new media as well as master new technologies, and how to change teachers' teaching concepts by using science and technology to promote and prosper education. The goal of higher education personnel training in China should be changed from previous "knowledge-based" and "applied" talents to "innovative" and "creative" talents. To impart knowledge to undergraduates is important; however, in order to fully promote their self-development, cultivating their comprehensive abilities such as learning ability, creativity and so on, is more important. Information education technology has changed the organizational forms and methods of education diversified the channels of obtaining information; therefore, the traditional role of knowledge transfers began to change. Computer networks enable undergraduates to acquire large amounts of knowledge and information independently without the help of their teachers; educators and educatees are no longer fixed in their roles as before, and using humanized machines to gain knowledge can make them transcend teachers in some respects. The intellectual authority of teachers is challenged.

Teachers are still the shapers of undergraduates' outstanding quality and sound personality. We should give full play to the advantages of modern education technology, strengthen educational work of undergraduates, and cultivate undergraduates with excellent quality as well as healthy and noble personality. Specifically, we should work together in the following combinations: First, to combine humancomputer interaction teaching with traditional face-to-face teaching. In the process of teaching, teachers should increase face-to-face communication with undergraduates appropriately without simply using modern teaching methods to replace their active roles as the main body of teaching activities. This face-to-face communication is not only an exchange of language and behavior, but also an exchange of mind and emotion between teachers and students. In the process of physical and mental growth of undergraduates, teachers play an irreplaceable role in demonstration. The teaching of knowledge, teaching styles and words and deeds exert a subtle influence on undergraduates and their optimistic outlook on life, rigorous scholarship and conscientious dedication, and set good examples for undergraduates. Second, to combine imparting modern scientific knowledge with shaping humanistic spirits. The complex network information and values diversity easily give rise to undergraduates lose their ways and judgments in the information world. While teaching modern scientific knowledge, teachers should also strengthen the training of undergraduates' humanistic qualities, teach undergraduates to recognize beauty and ugliness, truth and falsity, good and evil in network information, and cultivate undergraduates' rational understanding of the world, nations, society. The moral quality of undergraduates should be cultivated consciously through disciplinary penetration and integration of science and technology. Three, to combine classroom teaching with extra-curricular exchange. With the help of modern education technology, the frequency of classroom teaching and the opportunities for teachers and students to communicate with each other in the classes are reduced, so that teachers can use extra-curricular time reasonably and effectively or talk to undergraduates through online media such as QQ and MSN in order to understand them better and provide a complete education of enlightening students and making them sound personalities.

\section{B. Breaking the Boundaries and Establishing a New Cooperation Concept of New Teachers}

In the information age, the greatest contribution of network technology is to break the boundaries of time and space of interpersonal communication, making "people can contact each other easily regardless of distance" a reality. The various technologies characterized by computers and networks support the cooperation and exchange of geographically separated research units, disciplines and individuals, and provide a fairer access to acquire special knowledge and information, thus posing a major challenge to education reform to establish new types of cooperative relations and change systems separation and work isolation between individuals in the past.

Firstly, we need to build a new type of equality, democracy and cooperation relationship in mutual respect, mutual trust and mutual understanding between teachers and students. Under the conditions of modern education and technology, especially nowadays, in the rapid development stage of the Internet, teachers and students are equal to knowledge. Undergraduates have already grown up, and they can think independently, form their own opinions, raise doubts about teachers' viewpoints, use modern equipment to verify their own assumptions and talk about their ideas on the Internet. Relationship between teachers and students should be a kind of social relations of mutual understanding and recognition as well as mutual openness and admission.

Secondly, in modern education studies, teachers can cooperate with each other on research and exchange experience. During the process of teaching preparation, teachers in different regions can also cooperate to design curriculum, develop teaching software, discuss the 
innovation of teaching methods and modes, share experience and discuss solutions to difficult problems. In teaching, teachers and students are no longer bound by traditional classrooms, and the scope of collaborative communication can be extended from small groups in the class to the whole class and the communication among classes, grades, and even different colleges. Undergraduates' fellow students may be their classmates or undergraduates in other countries. In such collaborative learning, teachers can communicate with undergraduates through the Internet to promote undergraduates to learn and develop in a collaborative learning environment.

\section{Changing Learning Concepts to Learning and Researching Teachers}

Today's society is an information society and the information society is a learning society. In order to meet the challenge of modern educational technology for education and teaching, teachers must insist on lifelong learning, accepting new knowledge and mastering new technologies constantly. In addition to receiving training in business and educational technologies, we must learn new education theories constantly, acquire new ideas in education, establish correct education and talent views, raise awareness of modern educational technologies, be familiar with the application of modern educational technology, and continue to enhance teaching effect. Furthermore, information education technology replaces part of teachers' functions. When teachers are liberated from heavy teaching work, they can have more time and energy to engage in education and scientific researches, and information education technology raises claims of education, teaching research, and reform to teachers. Therefore, the role of teacher should be transformed from "book-keeper" to researching teacher. Modern educational technology provides an opportunity for teachers to show their talents and devote themselves to studying the law of education and teaching. Teachers should explore characteristics and laws of undergraduates learning deeply in the modern education technical environment and study how to improve students' abilities of learning, thinking, discovering, analyzing and solving problems by using new technologies.

\section{CONCLUSION}

In short, the progress and development of the times will surely bring greater challenges to university teachers. There are many methods and ways of the orientation of teachers' information quality and college teachers' roles in the era of education information. Only by learning and updating themselves constantly can teachers meet the needs of undergraduates and become the leaders of the times.

\section{REFERENCES}

[1] Feng Yonggang, "Relocation of Teachers' Roles under the Condition of Modern Education Technology", Journal of Inner Mongolia University for Nationalities, 2003.

[2] Lin Jing, "Reflections on the Teachers' Roles under the Target of New Curriculum", China Electronics Education, 2004.
[3] Su Jun, "Analysis on Music Teaching in Primary and Secondary Schools from the Status Quo of the Normal University Music Education,"J. Art Education, 2010,08: 50 + 69 . 